\title{
Phytochemical Profiling with Antioxidant and Antimicrobial Screening of Amaranthus viridis L. Leaf and Seed Extracts
}

\author{
Saud Asif Ahmed ${ }^{1 *}$, Sumaira Hanif ${ }^{1}$, Tehreema Iftkhar ${ }^{2}$ \\ ${ }^{1}$ Enzyme Biotechnology Lab., Department of Chemistry and Biochemistry, University of Agriculture, Faisalabad, Pakistan \\ ${ }^{2}$ Department of Botany, GC University, Faisalabad, Pakistan \\ Email: *saudasifahmed@gmail.com
}

Received August 14, 2013; revised September 14, 2013; accepted September 22, 2013

Copyright (C) 2013 Saud Asif Ahmed et al. This is an open access article distributed under the Creative Commons Attribution License, which permits unrestricted use, distribution, and reproduction in any medium, provided the original work is properly cited.

\begin{abstract}
Methanol extracts of the dried leaves and seeds of Amaranthus viridis were collected and used for phytochemicals and antibacterial analysis. By detecting the MIC and zone inhibition, the antibacterial activity was determined against different bacterial and fungal strains. The extract yields from the leaves and seeds ranged $5.5-6.1$ and $2.42 \%-3.72 \% \mathrm{w} / \mathrm{w}$, respectively. Phytochemical investigation of this plant determines that tanins $(6.07 \%-5.96 \%)$, saponins $(53 \%-32 \%)$, alkaloids $(13.14 \%-11.42 \%)$, protiens $(16.76 \%-24.51 \%)$ and glycosides $(63.2 \%-32.3 \%)$ were rich in leaves. The extracts also contained appreciable levels of total phenolic contents $(2.81-3.61 \mathrm{GAE}, \mathrm{g} / 100 \mathrm{~g})$, total flavanoid contents (18.4 - 5.42 QE, g/100 g) and DPPH free radical scavenging activity, showing $\mathrm{IC}_{50}(83.45-75.95 \mu \mathrm{g} / \mathrm{mL})$ along with reducing power was calculated. The MIC of extracts ranged $178-645 \mu \mathrm{g} / \mathrm{mL}$. The results of this study suggest the possibility of using the methanolic extracts in treating the diseases caused by the test organisms.
\end{abstract}

Keywords: Amaranthus viridis; Phytochemicals; DPPH. Lineolic Acid; Reducing Power; Leaf and Seed Extract

\section{Introduction}

Medicinal plants are used locally in the treatment of infections caused by fungi, bacteria, viruses and parasites. And over $60 \%$ of people in Nigeria rural areas depend on the traditional medicine for the treatment of their ailments [1]. Different plants have been used as a source of inspiration in the development of novel drugs [2]. Plant derived medicines are widely used because they are relatively safer than the synthetic alternatives, as they are easily available and cheaper [3]. Many plant species have been evaluated for their antimicrobial activity in the past 20 years [4]. The active principles of many drugs found in plants are recognized as secondary metabolites $[5,6]$.

Amaranthus viridis belongs to Amaranthaceae family. Amaranthus, communally known as Green amaranth or locally as "Karund", is a multinational genus of herbs. Amaranthus or Amaranth is defined as "never-fading flower" in Greek. Several species of Amaranthus are often considered as weeds, people around the world worth amaranths as leaf vegetables, cereals and ornamentals [7].

${ }^{*}$ Corresponding author.
Starchy foods are the main affix of developing countries as they provide both energy and proteins. These accounts in part for protein deficiency which overcomes among the general population are as acknowledged by Food and Agricultural Organization [8].

Antioxidants protect cells against damage caused by molecules known as free radicals. The antioxidant effects in plants are mainly due to the presence of phenolic compounds such as flavonoids, phenolic acids, tannins and phenolic diterpenes [9]. Oxidative damage is implicated in most disease processes such as cardiovascular disease, cancer, inflammatory conditions, asthma, liver disease and macular degeneration [10]. Epidemiological, clinical and laboratory research on flavonoids and other antioxidants suggest their use in the prevention and treatment of a number of these disorders $[11,12]$.

It is recently found that Amaranth seeds are rich in quite a few phytonutrients that take part in a significant role in inhibition of both oxidative chain reactions and free radicals reactions with tissue and membranes [13].

Existence of microorganisms causes spoilage, and results in reduction of the quality and quantity of processed foods. Some biologically active compounds isolated from 
herbs have been in use for the inhibition of growth pathogenic microbes because of the resistance against antibiotics [14]. The medicinal values of plants and vegetables are dictated by their phytochemical and other chemical constituents [15].

The pharmacological properties of amaranth products are considered of vital importance [16]. For reducing tissue swelling the leaves are well thought-out to be constructive, and they have a cleansing effect too. The plant has also been used curatively for diarrhea, dysentery, excessive menstrual flow, ulcers and intestinal hemorrhaging. For the treatment of intestinal bleeding, excessive menstruation, diarrhea and other related problems, a tea made from its leaves is used [17].

Aim of the present study was to evaluate phytochemicals, antioxidant and to detect the presence of natural therapeutic agents, especially those related to control the microbes that cause diseases in human beings from Amaranthus viridis leaf and seed extracts with absolute and $80 \%$ methanol solvent system.

\section{Materials and Methods}

\subsection{Collection and Pretreatment of Plant Material}

Fully matured leaves and seeds of Amaranthus viridis L. were collected from the fields of Lalliyan, which is a city in the Chiniot district of Punjab province, in Pakistan. These plants were identified by the Department of Botany, University of Agriculture Faisalabad. Fully matured leaves and seeds from the plant were selected because there is maximum metabolism in fully matured leaves and seeds as compared to young leaves and seeds. Specimens were dried at room temperature and stored in polyethylene bags at $4^{\circ} \mathrm{C}$.

\subsection{Chemical and Reagents}

1,1-diphenyl-2-picrylhydrazyl (DPPH), gallic acid, Folin-Ciocalteu reagent, sodium nitrite, Linoleic acid, butylated hydroxytoulene (BHT) were purchased from Sigma Chemical Company (St. Louis, USA) and anhydrous sodium carbonate, methanol, ethanol, diethyl ether, n-butanol, sulphuric acid, fehling solution, amyl alcohol, chloroform, olive oil, magnesium turnings, ammonia, ferric chloride, sodium nitrite and ammonium hydroxide used were obtained from Merck (Darmstadt, Germany). All culture media (nutrient agar, potato dextrose agar) purchased from Sigma Chemical Company (St. Louis, USA), broad spectrum antibiotic (ampicilin, benzyl penicillin, rifampicine and fluconazol) purchased from Sigma Chemical Company (St. Louis, USA), discs made up Backman filterpaper No. 1 and sterile solution of $10 \%(\mathrm{v} / \mathrm{v})$ DMSO in water were purchased from Oxiod (Hampshire, UK).

\subsection{Prepration of Plant Extract}

Methanolic extraction of the plants material was carried out by suspending 100 grams of the powders of Amaranthus in $1000 \mathrm{ml}$ of absolute methanol and $80 \%$ methanol (80:20, methanol: water, v/v).

The extraction was allowed to stand for 72 hours at $37^{\circ} \mathrm{C}$. The extracts were filtered first through cotton wool, then through Whatman filter paper No.1 $(125 \mathrm{~mm})$ and were dried using a rotary evaporator. They were transferred into sterile bottles and kept in refrigerator until used.

\subsection{Phytochemical Analysis}

Phytochemical screening for the presence of Tannins, alkaloids, glycosides, flavonoids, and phenolic was performed using standard procedures [18,19].

\subsubsection{Qualitative Analysis of Phytochemicals Alkaloids}

The extracts were evaporated to dryness and the residues were heated on a boiling water bath with $2 \% \mathrm{Hy}-$ drochloric, cooled, filtered and treated with the Mayer's reagent. The sample was then observed for the presence of yellow precipitation or turbidity $[19,20]$.

\section{Flavonoids}

$1.5 \mathrm{ml}$ of $50 \%$ methanol was added to $4 \mathrm{ml}$ of extracts. After warming add magnesium fillings followed by few drops of concentrated hydrochloric acid. A pink or red colour indicates the presence of flavonoid [19,20].

\section{Tannins}

A portion of the extract was diluted with distilled water in a ratio of 1:4 and few drops of $10 \%$ ferric chloride solution were added. A blue or green color indicates the presence of tannins [21].

\section{Saponins}

A small quantity of the methanolic extract was boiled. The mixture was filtered and $2.5 \mathrm{ml}$ of the filtrate was added to $10 \mathrm{ml}$ of the distilled water in a test tube and shaked well for about 30 seconds and observed for frothing [18].

\section{Glycosides}

In methanolic extract Fehlings reagent was added and boiled for 2 minutes. A brick red coloration indicates the presence of glycosides.

\subsubsection{Quantitative Analysis \\ Estimation of Alkaloids Contents}

The alkaloid content of each extract was determined [19]. About $5.0 \mathrm{~g}$ of each sample was weighed into a 250 $\mathrm{ml}$ beaker, and a $200 \mathrm{ml}$ of $10 \%$ acetic acid in ethanol was added, and allowed to stand for $4 \mathrm{hrs}$. This was filtered using whatmann No.42 filtered paper, concentrated in water bath to one fourth $(50 \mathrm{ml})$ of the original volume. 
Then, concentrated $\mathrm{NH}_{4} \mathrm{OH}$ was added dropwise to each Flavonoids extract until the precipitate was complete. The suspension was allowed to settle and the precipitate was collected, washed with $\mathrm{NH}_{4} \mathrm{OH}$ and then filtered. The residue was dried and weighed. The percentage alkaloid was then calculated.

\section{Estimation of Tannin Content}

$500 \mathrm{mg}$ of plant sample was weighed and transferred to $50 \mathrm{ml}$ flask. Then added $50 \mathrm{ml}$ of distilled water and stirred for $1 \mathrm{~h}$. Sample was filtered into a $50 \mathrm{ml}$ volumetric flask and the volume was made up to the mark. $5 \mathrm{ml}$ of the filtered sample was pipette into test tube and then mixed with $2 \mathrm{ml}$ of $0.1 \mathrm{M}$ ferric chloride. The absorbance was measured using spectrophotometer at $395 \mathrm{~nm}$ wavelength within $10 \mathrm{~min}[19,20]$.

\section{Estimation of Saponin Content}

Saponin content was determined by the reported method [22]. About $2.0 \mathrm{~g}$ of each extract was mixed with $100 \mathrm{ml}$ of $20 \%$ ethanol, and were incubated in a water bath at $55^{\circ} \mathrm{C}$ for $4 \mathrm{hrs}$ with stirring. The mixture was filtered and the extract was re-extracted with $200 \mathrm{ml}$ of $20 \%$ ethanol. The combined extract was concentrated to $40 \mathrm{ml}$ in a water bath at $90^{\circ} \mathrm{C}$. The concentrate was then transferred into a $20 \mathrm{ml}$ separatory funnel and $20 \mathrm{ml}$ diethyl ether was added, and shaken vigorously. The aqueous layer was recovered while the ether layer was discarded, the purification process was heated and $60 \mathrm{ml}$ of n-butanol added. The combined n-butanol extracts were washed twice with $10 \mathrm{ml}$ of $5 \%$ aqueous $\mathrm{NaCl}$, and the remaining solution was heated in a water bath. After evaporation, the samples were dried in the oven to a constant weight, and the percentage saponin content was calculated.

\section{Estimation of Glycosides}

The glycosides content of the extracts was determined by dissolving $5.0 \mathrm{~g}$ of the extracts in $50 \mathrm{ml}$ of $50 \%$ $\mathrm{H}_{2} \mathrm{SO}_{4}$ in test tubes. The mixture was heated in boiling water for 15 minutes, and $5 \mathrm{ml}$ of Fehling solution added, and the mixture boiled. A red precipitate in each extract tested, indicated the presence of glycosides. The percentage glycoside was calculated $[19,20]$.

\subsection{Antioxidant Activity}

\subsubsection{Total Phenolic Contents (TPC) \& Total Flavonoid Contents (TFC)}

Total phenolic contents (TPC) were determined using the Folin-Ciocalteu reagent method and Gallic acid was used as Gallic acid Equivalent (GAE). Total flavonoid contents (TFC) in the leaf and seed extracts were determined following the modified procedure [23], and Quericitin was used as standard as Quericitin Equivalent (QE).

\subsubsection{DPPH Radical Scavenging Assay}

The 1, 1-diphenyl-2-picrylhydrazyl (DPPH) radical assay was carried out spectrophotomerically [24]. The percent inhibition was calculated as:

$$
\text { \%Inhibition }=100 \times(\text { A blank }- \text { A sample } / \text { A blank })
$$

where A blank the absorbance of the control reaction (containing all reagents except the test sample), and A sample is the absorbance of test samples. $\mathrm{IC}_{50}$ values, which represented the concentration of Amaranthus viridis that caused $50 \%$ inhibition, were calculated from the plot of percentage against concentration.

\subsubsection{Determination of Antioxidant Activity in Linoleic Acid System}

The antioxidant activity of the Amaranthus viridis extracts materials was also determined by measuring the oxidation of linoleic acid [25]. $5 \mathrm{mg}$ of Amaranthus viridis extracts was added separately to a solution of linoleic acid $(0.13 \mathrm{~mL}), 99.8 \%$ ethanol $(10 \mathrm{~mL})$ and $10 \mathrm{~mL}$ of 0.2 M Sodium Phosphate buffer $(\mathrm{pH}=7)$. The mixture was made up to $25 \mathrm{~mL}$ with distilled water and incubated at $40^{\circ} \mathrm{C}$ up to 360 hours. Extent of oxidation was measured by peroxide value applying Thiocyanate method. Briefly, $10 \mathrm{~mL}$ of ethanol $(75 \% \mathrm{v} / \mathrm{v}), 0.2 \mathrm{~mL}$ of aqueous solution of Ammonium Thiocyanate $(30 \% \mathrm{w} / \mathrm{v}), 0.2 \mathrm{~mL}$ of sample solution and $0.2 \mathrm{~mL}$ of ferrous chloride $\left(\mathrm{FeCl}_{2}\right)$ solution $(20 \mathrm{mM}$ in $3.5 \% \mathrm{HCl} ; \mathrm{v} / \mathrm{v})$ added sequentially. After 3 min of stirring, the absorption was measured at $500 \mathrm{~nm}$ using a spectrophotometer (U-2001, Hitachi Instruments Inc., Tokyo, Japan). A negative control contained all reagents with exception of extracts. Synthetic antioxidants Butylated Hydroxytoluene (BHT) (also we can use ascorbic acid) was used as positive control. The maximum per oxidation level was observed at $360 \mathrm{~h}$ (15 days) in sample that possesses no antioxidant component percent inhibition of linoleic acid oxidation was calculated with the following equation:

100 - [(Abs. increase of sample at $360 \mathrm{~h} / \mathrm{Abs}$. increase of control at $360 \mathrm{~h}$ ) $\times 100$ ], to express antioxidant activity.

\subsubsection{Determination of Reducing Power}

The reducing power of the Amaranthus viridis extracts was determined according to the spectrophotometric method [26]. Concentrated extract $(0-10.0 \mathrm{mg})$ was mixed with sodium phosphate buffer $(5.0 \mathrm{~mL}, 0.2 \mathrm{M}, \mathrm{pH} 6.6)$ and potassium ferricyanide $(5.0 \mathrm{~mL}, 1.0 \%)$; the mixture was incubated at $50^{\circ} \mathrm{C}$ for $20 \mathrm{~min}$. Then $5 \mathrm{~mL}$ of $10 \%$ Trichloro Acetic Acid was added and the mixture centrifuged at $980 \mathrm{~g}$ for $10 \mathrm{~min}$ at $5^{\circ} \mathrm{C}$ in a refrigerated centrifuge (CHM-17; Kokusan Denki, Tokyo, Japan). The upper layer of the solution $(5.0 \mathrm{~mL})$ was decanted and diluted with $5.0 \mathrm{~mL}$ of distilled water and ferric chloride $(1.0 \mathrm{~mL}, 0.1 \%)$, and absorbance read at $700 \mathrm{~nm}$ using spectrophotometer (U-2001, Hitachi Instruments Inc., 
Tokyo, Japan). All samples were analyzed thrice and results averaged.

\subsection{Antimicrobial Activity}

\subsubsection{Microbial Strains}

Staphylococcus aureus and Escherichia coli, together with two pathogenic fungi (Fussarium solani and Rhizopus oligosporus) were used as microbial strains. The organisms were purchased from ATTC. These bacterial and fungal strains were cultured at $37^{\circ} \mathrm{C}$ and $28^{\circ} \mathrm{C}$ over night in an incubator (Memmert Germany).

\subsubsection{Disc Diffusion Method}

The antimicrobial activity of the prepared extracts was determined by using disc diffusion method [27]. The inoculated extracts were than examined for inhibition zones (in $\mathrm{mm}$ ) by zone reader which indicates antimicrobial activity The discs (6 $\mathrm{mm}$ in diameter) were impregnated with $20 \mu \mathrm{g} / \mathrm{m}$, sample extracts $(20 \mu \mathrm{g} / \mathrm{disc})$ and placed on inoculated agar. Rifampicine (20 $\mu \mathrm{g} / \mathrm{disc})$ (Oxiod) and Fluconazol $(20 \mu \mathrm{g} / \mathrm{disc})$ (Oxiod) were used as positive reference for bacteria and fungi, respectively.

\subsubsection{Determination of Minimum Inhibitory Concentration (MIC)}

The medium used in this assay was Isosensitest and standardized bacterial colony numbers was taken, adopting $5 \times 105 \mathrm{CFU} / \mathrm{mL}$ final concentration of strains of bacterial species. After preparing microbial culture and resazurin solution glass plates were prepared. These were all prepared under aseptic conditions. A 96 well plate was sterilized and labeled. $100 \mu \mathrm{L}$ of test material in $10 \%(\mathrm{v} / \mathrm{v}) \mathrm{DMSO} /$ sterile water $(10 \mathrm{mg} / \mathrm{mL}$ for crude extracts) was pipetted into the first row of the plate. In rest of the wells $50 \mu \mathrm{L}$ of nutrient broth was added and serial dilutions were made by adding $50 \mu \mathrm{L}$ of the test sample in serially descending concentrations. In each well $10 \mu \mathrm{L}$ of resazurin indicator solution was added. At the end 10 $\mu \mathrm{L}$ of bacterial suspension $\left(5 \times 10^{6} \mathrm{CFU} / \mathrm{mL}\right)$ was added to each well to get a concentration of $5 \times 10^{5} \mathrm{CFU} / \mathrm{mL}$. To avoid bacteria to become dehydrated each plate was wrapped loosely with cling film. Every plate had a set of control column having broad-spectrum antibiotic as positive control (Ampicilin for bacteria: Benzyl penicillin for fungi). That column has all solutions except the test compound, and another column with all solutions with the exception of the bacterial solution adding $10 \mathrm{~L}$ of nutriaent broth instead. The plates were prepared in triplicate, and placed in an incubator set at $37^{\circ} \mathrm{C}$ for $18-24 \mathrm{~h}$. The color change was then assessed visually. Any color changes from purple to pink or colorless were recorded as positive. The lowest concentration at which color change occurred was taken as the MIC value. The average of three values was calculated and that was the MIC for the test material and microbial strain.

\section{Results and Discussion}

\subsection{Results}

The present study carried out on the plant samples revealed the presence of medicinally active constituents. The phytochemical characters of Amaranthus viridis was investigated and summarized in Tables 1 and 2. Alkaloids, tannins, saponins and glycosides were present in both leaf and seed. Quantitative estimation of the percentage crude chemical constituents in Amaranthus viridis was studied and summarized in Table 2. Leaves contained the highest percentage crude yield of alkaloids, tannins, saponins and cardiac glycosides as presented in Graph 1. They were known to show medicinal activity as well as exhibiting physiological activity [18].

Table 3 contains the percentage yield and antioxidant activity of Amarunthus viridis leaf and seed extracts. Graph 2 showed that the maximum extract yields for leaf and seed were obtained with $80 \%$ methanol (6.1 $\mathrm{g} / 100 \mathrm{~g})$ and $100 \%$ methanol $(3.72 \mathrm{~g} / 100 \mathrm{~g})$, respectively [28]. The highest DPPH activity, TP and TF content was found in $100 \%$ methanol seed extract and lowest for $100 \%$ methanol leaf extracts as shown in Table 3. The comparative values for TP and TF contents having DPPH among leaves and seeds with different extracting solvent combinations is presented in Graphs 2, 3 and $\mathbf{4}$ respectively.

The higher percentage inhibition of linoleic acid oxidation by the extract compared with the reference drug, BHT, suggests a marked and higher antioxidant activity Table 4. Furthermore, the percentage inhibition of linoleic acid oxidation (67.57\%) obtained for the Amaranthus viridis in this study is similar to that $(68.41 \%)$ reported by [29].

At physiological $\mathrm{pH}$ (7.4), ferrous ions $\left(\mathrm{Fe}^{2+}\right)$, in the presence of oxygen and phosphate ions $\left(\mathrm{PO}_{4}^{2-}\right)$, exist only transiently before being auto-oxidized to ferric ion $\left(\mathrm{Fe}^{3+}\right)$. During this process, an electron is transferred from iron to oxygen to form a superoxide radical anion and hydroperoxyl radical $\left(\mathrm{HO}_{2} \cdot\right)$ by Fenton reaction. The

Table 1. Qualitative analysis for phytochemical constituents of leaf and seed extract of Amaranthus viridis.

\begin{tabular}{ccc}
\hline \multirow{2}{*}{$\begin{array}{c}\text { Phytochemical } \\
\text { constituent }\end{array}$} & \multicolumn{2}{c}{ Amaranthus viridis } \\
\cline { 2 - 3 } & Leaves & Seeds \\
\hline Tannins & + & + \\
Saponins & - & - \\
Flavonoids & + & + \\
Cardiac glycosides & + & + \\
\hline
\end{tabular}

+ represents presence of the phytoconstituent; - represents absence of the phytoconstituent. 
Table 2. Quantitative analysis for phytochemical constituents of leaf and seed extract of Amaranthus viridis.

\begin{tabular}{|c|c|c|c|c|c|}
\hline \multirow[b]{2}{*}{ Part of plant used } & \multicolumn{5}{|c|}{ Phytochemical Constituents ( $\%$ age) } \\
\hline & Alkaloids & Tannins & Saponnins & Glycosides & Protiens \\
\hline Leaves & $13.14 \pm 0.86$ & $6.07 \pm 0.93$ & $53.0 \pm 0.50$ & $63.2 \pm 0.80$ & $16.76 \pm 1.02$ \\
\hline Seeds & $11.42 \pm 0.58$ & $5.96 \pm 0.54$ & $32.0 \pm 0.70$ & $32.0 \pm 0.92$ & $24.51 \pm 1.09$ \\
\hline
\end{tabular}

Table 3. Percentage yield and Antioxidant activity of Amaranthus viridis leaf and seed extracts.

\begin{tabular}{cccccc}
\hline Part of plant used & Methanol extract & $\begin{array}{c}\text { \% age yield } \\
(\mathrm{g} / 100 \mathrm{~g} \text { of } \mathrm{DM})\end{array}$ & TP contents & TF contents & $\begin{array}{c}\text { DPPH assay }(\mu \mathrm{g} / \mathrm{mL}) \\
\mathrm{IC}_{50}\end{array}$ \\
\hline \multirow{2}{*}{ Leaves } & $100 \%$ & $5.5^{\mathrm{a}} \pm 0.13$ & $1.4^{\mathrm{a}} \pm 0.5$ & $2.78^{\mathrm{b}} \pm 0.20$ & $14.27^{\mathrm{a}} \pm 2.2$ \\
& $80 \%$ & $6.1^{\mathrm{a}} \pm 0.14$ & $2.81^{\mathrm{a}} \pm 0.2$ & $18.4^{\mathrm{a}} \pm 0.30$ & $83.45^{\mathrm{a}} \pm 3.87$ \\
\multirow{2}{*}{ Seeds } & $100 \%$ & $3.72^{\mathrm{ab}} \pm 0.11$ & $3.61^{\mathrm{a}} \pm 0.4$ & $5.42^{\mathrm{a}} \pm 0.20$ & $46.55^{\mathrm{a}} \pm 2.94$ \\
& $80 \%$ & $2.42^{\mathrm{b}} \pm 0.04$ & $3.27^{\mathrm{a}} \pm 0.39$ & $2.51^{\mathrm{b}} \pm 0.07$ & $75.95^{\mathrm{a}} \pm 3.33$ \\
\hline
\end{tabular}

Values are mean \pm SD of samples analyzed individually in triplicate. "Total phenolic contents in Gallic acid equivalent. ${ }^{* *}$ Total flavonoid contents in Quericitin equivalent.

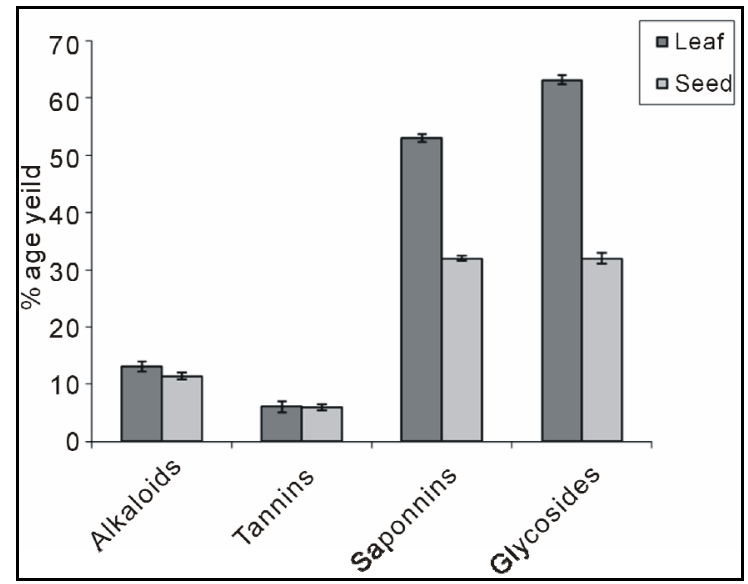

Graph 1. Quantitative analysis for phytochemical constituents of leaf and seed extract of Amaranthus viridis.

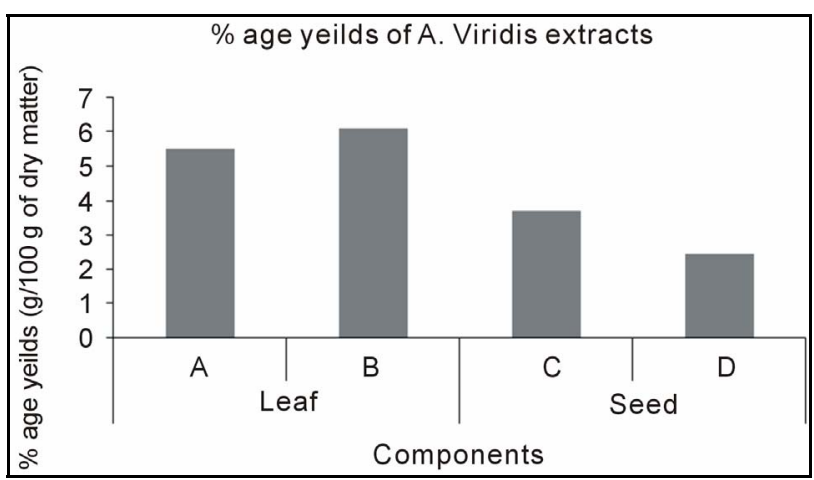

Graph 2. Percentage yield of Amaranthus viridis leaf and seed extracts.

concentration-dependent, high reducing power of the aqueous extract of Amaranthus viridis leaves suggests that the extract possessed the ability to be effective, under physiological conditions, in reducing the transition

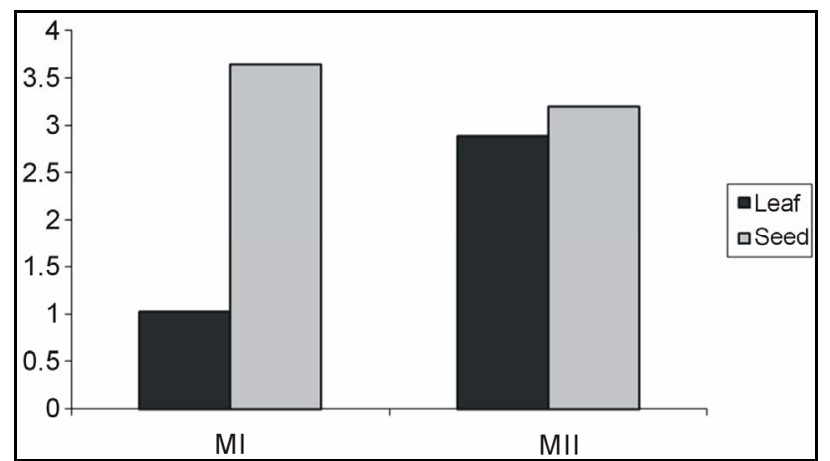

Graph 3. Total phenolic content of Amaranthus viridis leaf and seed extracts.

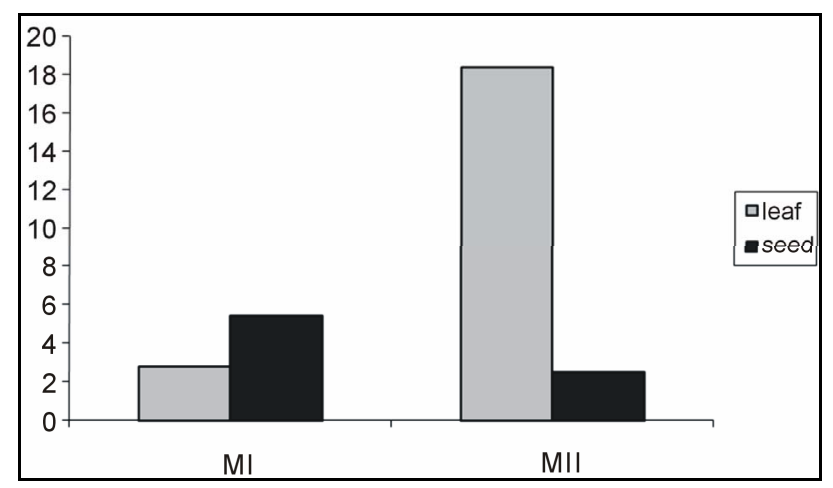

Graph 4. Total flavonoid content of Amaranthus viridis leaf and seed extracts.

state of iron and consequently, the rate at which super oxide and hydroperoxyl radicals are generated from the metal Table 5. A strong relationship between the total phenolic content and reducing activity in fruits and vegetables has been reported [26]. Therefore, the reducing power of the extract may be attributed to its phenolic content. 
Table 4. Percent inhibition of linoleic acid per oxidation of leaf of Amaranthus viridis extracts.

\begin{tabular}{ccccc}
\hline \multirow{2}{*}{$\begin{array}{c}\text { Inhibition of } \\
\text { Per oxidation }\end{array}$} & \multicolumn{4}{c}{ Lxtracts } \\
\cline { 2 - 5 } & $100 \%$ & $80 \%$ & $100 \%$ & $80 \%$ \\
\hline \%age & $59.2 \pm 1.7^{\mathrm{c}}$ & $67.4 \pm 2.1^{\mathrm{b}}$ & $54.9 \pm 2.1^{\mathrm{d}}$ & $60.8 \pm 2.4^{\mathrm{a}}$ \\
\hline
\end{tabular}

Values (mean $\pm \mathrm{SD}$ ) are of three samples of Amaranthus viridis extract, analyzed individually in triplicate. Means followed by different superscript letter in the same row present significant difference $(p<0.05)$.

Table 5. Reducing power of different Amaranthus viridis leaf extracts.

\begin{tabular}{|c|c|c|c|c|c|}
\hline \multirow{3}{*}{$\begin{array}{l}\text { Conc. } \\
\mathrm{mg} / \mathrm{ml}\end{array}$} & \multicolumn{4}{|c|}{ Extracts } & \multirow{3}{*}{ BHT } \\
\hline & \multicolumn{2}{|c|}{ Leaves } & \multicolumn{2}{|c|}{ Seeds } & \\
\hline & $100 \%$ & $80 \%$ & $100 \%$ & $80 \%$ & \\
\hline 2 & $0.06 \pm 0.01$ & $0.08 \pm 0.01$ & $0.04 \pm 0.01$ & $0.07 \pm 0.01$ & $0.73 \pm 0.04$ \\
\hline 4 & $0.39 \pm 0.01$ & $0.26 \pm 0.08$ & $0.07 \pm 0.02$ & $0.08 \pm 0.02$ & $0.95 \pm 0.05$ \\
\hline 6 & $0.65 \pm 0.04$ & $0.58 \pm 0.10$ & $0.34 \pm 0.03$ & $0.25 \pm 0.02$ & $1.14 \pm 0.06$ \\
\hline 8 & $0.84 \pm 0.05$ & $1.16 \pm 0.11$ & $0.57 \pm 0.03$ & $0.38 \pm 0.04$ & $1.54 \pm 0.08$ \\
\hline 10 & $1.27 \pm 0.06$ & $1.60 \pm 0.13$ & $1.01 \pm 0.04$ & $0.75 \pm 0.04$ & $1.80 \pm 0.09$ \\
\hline
\end{tabular}

Values (mean $\pm \mathrm{SD}$ ) are of three samples of Amaranthus viridis extract, analyzed individually in triplicate. Means present significant difference $(p<$ $0.05)$.

\subsection{Antimicrobial Activity}

The leaves and seeds of Amaranthus viridis extracts showed consider antimicrobial activities in disc diffusion assay as shown in Figures 1(a) \& (b). The quantitative estimation for antimicrobial activity for Amaranthus viridis leaf and seed extracts against food-borne and pathogenic microorganisms are showed in Tables 6 and 7. In leaf two solvent systems show different result as: $100 \%$ methanol leaf extract $(25 \mathrm{~mm})>80 \%$ methanol leaf extract $(23 \mathrm{~mm})$ and for seed extracts, $100 \%$ methanol seed extract $(17 \mathrm{~mm})<80 \%$ methanol seed extract $(19 \mathrm{~mm})$. The trend for antifungal activity was same to that of antibacterial activity except that the efficacy towards fungal strain was not much effective as for bacterial strains. The comparative analysis for antibacterial and antifungal activities of Amaranthus viridis leaves and seeds with different sompositions of methanolic solvents with highly signinificant values are presented in Graphs 5, 6 \& 7 respectively. The trend for antifungal activity was $100 \%$ methanol leaf $>100$ methanol seed $>80 \%$ methanol leaf $>80 \%$ methanol seed. The currents results support the earlier findings which demonstrate the presence of antimicrobial activity in seeds of Amarathaceae [30,31].

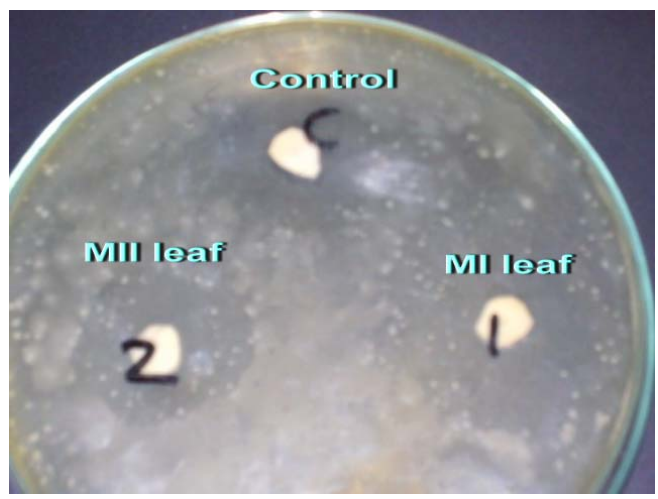

(a)

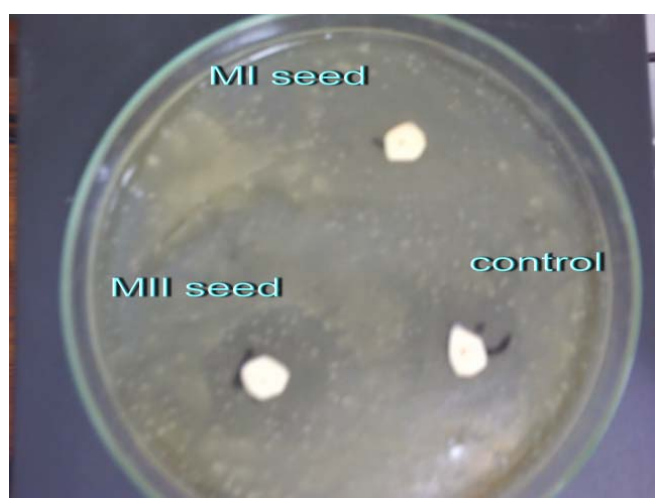

(b)

Figure 1. Inhibition zones of Amaranthus viridis Leaf (a) and Seed (b) extracts.

Table 6. Antimicrobial activity of Amaranthus viridis methanolic leaf and seed extracts $(100 \%$ and $80 \%)$.

\begin{tabular}{cccccc}
\hline \multirow{2}{*}{$\begin{array}{c}\text { Part of } \\
\text { plant used }\end{array}$} & Methanol & \multicolumn{4}{c}{ Zones of growth inhibition mm } \\
\cline { 3 - 6 } & extract & S. aureus & E. coli & F. solani & R. oligosporus \\
\hline \multirow{2}{*}{ Leaves } & $100 \%$ & $24^{\mathrm{ab}}$ & $16^{\mathrm{a}}$ & $17^{\mathrm{ab}}$ & $9.0^{\mathrm{c}}$ \\
& $80 \%$ & $23^{\mathrm{ab}}$ & $12^{\mathrm{b}}$ & $15^{\mathrm{b}}$ & $8.0^{\mathrm{b}}$ \\
\multirow{2}{*}{ Seeds } & $100 \%$ & $16^{\mathrm{c}}$ & $11^{\mathrm{b}}$ & $13^{\mathrm{c}}$ & $5.0^{\mathrm{bc}}$ \\
& $80 \%$ & $18^{\mathrm{c}}$ & $10^{\mathrm{b}}$ & $10^{\mathrm{c}}$ & $3.0^{\mathrm{c}}$ \\
Control $^{*}$ & $100 \%$ & $26^{\mathrm{a}}$ & $17^{\mathrm{a}}$ & $18^{\mathrm{a}}$ & $16^{\mathrm{a}}$ \\
\hline
\end{tabular}

${ }^{*}$ Control used was Ampicillin (S. aureus, E. coli) and Benzyl penicillin (F. solani, R. oligosporus).

Table 7. Minimum inhibitory concentration of Amaranthus viridis leaf and seed methanolic extracts against the selected bacterial and fungal strains.

\begin{tabular}{cccccc}
\hline $\begin{array}{c}\text { Part of } \\
\text { plant } \\
\text { used }\end{array}$ & $\begin{array}{c}\text { Methanol } \\
\text { extracts }\end{array}$ & S. aureus & E. coli & F. solani & $\begin{array}{c}R . \\
\text { oligosporus }\end{array}$ \\
\hline \multirow{2}{*}{ Leaves } & $100 \%$ & $179^{\mathrm{ab}} \pm 1.28$ & $398^{\mathrm{a}} \pm 1.26$ & $436 \pm 1.46$ & $302^{\mathrm{c}} \pm 1.36$ \\
& $80 \%$ & $182^{\mathrm{ab}} \pm 1.68$ & $603^{\mathrm{b}} \pm 2.36$ & $491^{\mathrm{b}} \pm 1.76$ & $352^{\mathrm{b}} \pm 2.42$ \\
& $100 \%$ & $428^{\mathrm{c}} \pm 1.36$ & $639^{\mathrm{b}} \pm 1.26$ & $602^{\mathrm{c}} \pm 1.89$ & $482^{\mathrm{bc}} \pm 1.27$ \\
Seeds & $80 \%$ & $403^{\mathrm{c}} \pm 2.36$ & $645^{\mathrm{b}} \pm 1.48$ & $641^{\mathrm{c}} \pm 2.38$ & $547^{\mathrm{c}} \pm 2.38$ \\
& \multirow{2}{*}{ Control Methanol } & $141^{\mathrm{a}} \pm 1.31$ & $381^{\mathrm{a}} \pm 2.39$ & $391^{\mathrm{a}} \pm 2.48$ & $436^{\mathrm{a}} \pm 2.17$
\end{tabular}




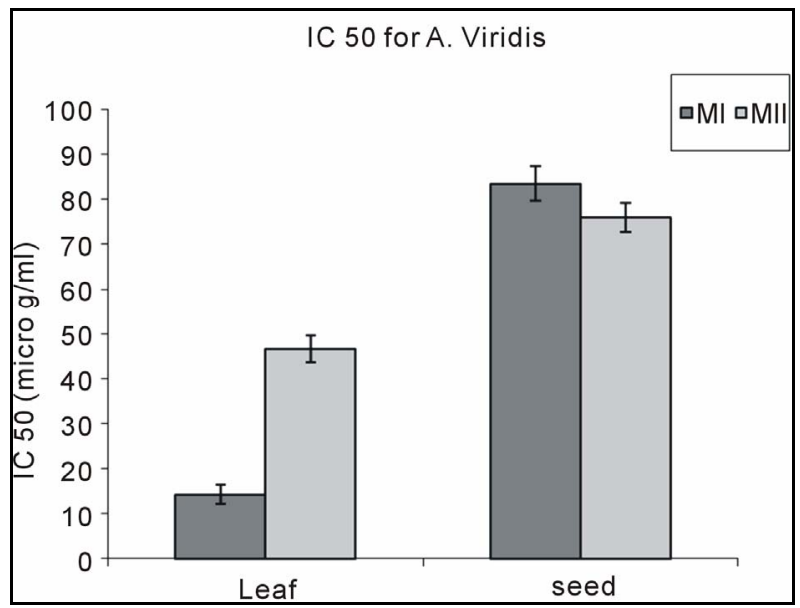

Graph 5. DPPH of Amaranthus viridis leaf and seed extracts.

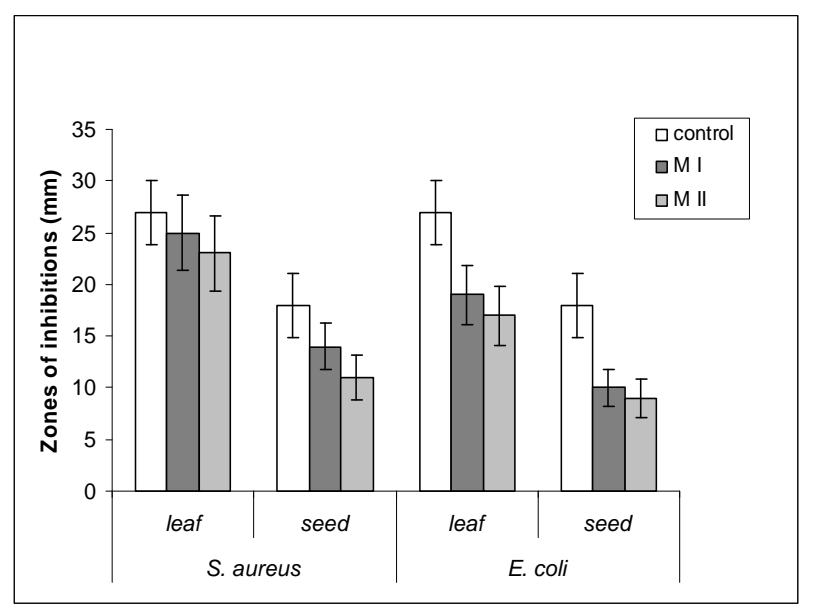

Graph 6. Comparison of antibacterial activity of Amaranthus viridis methanolic leaf and seed extracts $(100 \%$ and $\mathbf{8 0 \% )}$ against Staphylococcus aureus and Escherichia coli with that of antibiotic.

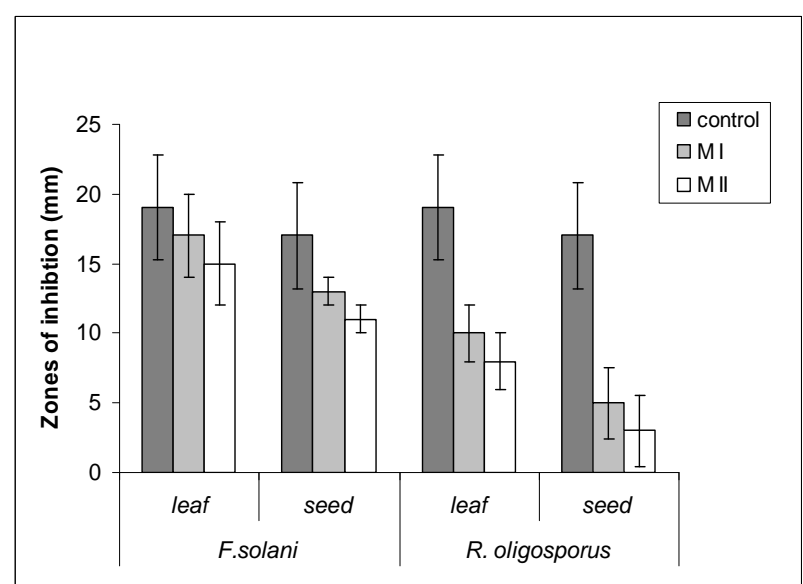

Graph 7. Comparison of antifungal activity of Amaranthus viridis methanolic leaf and seed extracts $(100 \%$ and $80 \%)$ against Fussarium solani and Rhizopus oligosporus with that of antibiotic.

\section{Conclusion}

From the study it was concluded that the edible plant species Amaranthus viridis from underutilized plant family had a rich amount of valuable ingredients that are beneficial for health.

\section{REFERENCES}

[1] A, Ghani, E. M. Abdulrahman and J. A. Onaolapo, "Chemical and Microbiological Evaluation of Some Nigerian Traditional Preparations," The Report, Nigeria, 1989.

[2] J. Robbers, M. Speedie and V. Tyler, "Pharmacognosy and Pharmacobiotechnology," Williams, Wilkins Baltimore, 1996.

[3] M. M. Iwu, A. R. Duncan and C. O. Okunji, "New Antimicrobials of Plant Origin," In: J. Janick, Ed., Prospective on New Crops and New Uses, ASHS Press, Alexandria, 1999.

[4] M. C. Castello, P. Anita, C. Naresh and S. Madhuri, "Antimicrobial Activity of Crude Extracts from Plant Parts and Corresponding Calli of Bixaorellina. Ind," Journal of Experimental Biotechnology, Vol. 40, No. 12, 2002, pp. 1378-1381.

[5] A. Ghani, "Introduction to Pharmacognosy," Ahmadu Bello University Press, Nigeria, 1990.

[6] I. N. Dobelis, "Magic and Medicine of Plants," The Readers Digest Association Inc., New York, 1993.

[7] G. F. Stallknecht and J. R. Schulz-Schaeffer, "Amaranth Rediscovered New Crops," Wiley, New York, 1993.

[8] O. Ladeji, Z. S. Okoye and T. Ojobe, "Chemical Evaluation of the Nutritive Value of Leaf of Fluted Pumpkin," Food Chemistry, Vol. 53, No. 4, 1995, pp. 353-355. doi:10.1016/0308-8146(95)99826-L

[9] O. Polterait, "Antioxidants and Free-Radical Scavengers of Natural Origin," Current Organic Chemistry, Vol. 1, No. 4, 1997, pp. 415-440.

[10] J. K. Willcox, S. L. Ash and G. L. Catignani, "Antioxidants and Prevention of Chronic Diseases," Critical Reviews in Food Science and Nutrition, Vol. 44, No. 4, 2004, pp. 275-295. doi:10.1080/10408690490468489

[11] H. M. Burkill, "The Useful Plants of West Tropical Africa,” Royal Botanical Garden Kew, London, 1984.

[12] T. O. Odugbemi, "Outlines and Pictures of Medicinal Plants from Nigeria," University of Lagos Press, Nigeria, 2006.

[13] R. Y. Nsimba, H. Kikuzaki and Y. Konishi, "Antioxidant Activity of Various Extracts and Fractions of Chonopodium quinoa and Amaranthus Species Seed," Food Chemistry, Vol. 106, No. 2, 2008, pp. 760-766. doi:10.1016/j.foodchem.2007.06.004

[14] M. G. Abukakar, A. N. Ukwuani and R. A. Shehu, "Phytochemical Screening and Antibacterial Activity of Tamarindus indica Pulp Extract," Asian Journal of Biochemistry, Vol. 3, No. 2, 2008, pp. 134-138. doi:10.3923/ajb.2008.134.138

[15] H. S. M. Fallah, H. R. Alavian, M. R. Heydari and K. Abolmaali, "The Efficacy of Liv-52 on Liver Cirrhotic Patients: A Randomized, Double Blind, Placebo-Con- 
trolled First Approach," Journal of Phytomedicine, Vol. 12, No. 9, 2005, pp. 619-624. doi:10.1016/j.phymed.2004.10.003

[16] K. H. Kyung, K. M. Jeong, C. H. Yon, K. Eun-Ki and S. D. Hoon, "Antioxidant and Antidiabatic Effects of Amaranth (Amaranthus cruentus) in Diabatic Rat," Cell Biochemistry and Function, Vol. 24, No. 3, 2006, p. 1.

[17] S. Yue and H. Sun, "The Characteristics and Prospects of Amaranthus Food in China," The 2nd International Symposium on New and Nononventional Plants: Their Perspective Use, Putstchino, 1997, pp. 138-139.

[18] A. Sofowora, "Medicinal Plant and Traditional Medicine in Africa," Wiley and Sons Limited, Chichester, 1993.

[19] J. B. Harborne, "A Guide to Modern Techniques of Plant Analysis," Chapman and Hall, London, 1973.

[20] V. Tyler, "Phytomedicines in Western Europe: Their Potential Impact on Herbal Medicine in the United States," Herbalgram, Vol. 30, 1994, pp. 24-30.

[21] W. C. Evans, "Trease and Evans Phamacognosy," Bailere Traiadal, London, 1989.

[22] B. O. Obadoni and P. O. Ochuka, "Phytochemical Studies and Comparative Efficacy of the Crude Extracts of Some Homeostatic Plants in Edo and Delta States of Nigeria," Global Journal of Pure Applied Sciences, Vol. 8, No. 2, 2001, pp. 203-208.

[23] V. Dewanto, K. K. Adom and R. H. Liu, "Thermal Processing Enhances the Nutritional Value of Tomatoes By Increasing Total Antioxidant Activity," Journal of Agricultural and Food Chemistry, Vol. 50, No. 10, 2002, pp. 3010-3014. doi:10.1021/if0115589

[24] P. R. Miliauskas, Venskutonis and T. A. Van Beek, "Screening of Radical Scavenging Activity of Some Medicinal and Aromatic Plant Extracts," Journal of Food Chemistry, Vol. 85, No. 2, 2004, pp. 231-237. doi:10.1016/j.foodchem.2003.05.007

[25] J. C. Lee, H. R. Kim and K. J. Jim, “Antioxidant Property of an Extract of the Stem of Opuntia Ficus-Indica Var. saboten," Journal of Agricultural and Food Chemistry, Vol. 40, No. 4, 2002, pp. 6490-6496. doi:10.1021/jf020388c

[26] A. Yildrim, A. Mavi and A. A. Kara, "Determination of Antioxidant and Antimicrobial Activities of Rumex Crispus L. Extracts," Journal of Agricultural and Food Chemistry, Vol. 49, No. 8, 2001 pp. 4083-4089. doi:10.1021/jf0103572

[27] National Committee for Clinical Laboratory Standards, "Methods for Dilution Antimicrobial Susceptibility Tests for Bacteria That Grow Aerobically," National Committee for Clinical Laboratory Standards, Wayne, 2000.

[28] N. Ozsoy, O. K. Tilmaz and C. R. Yanardag, "In Vitro Antioxidant Activity of Amaranthus lividus L.," Journal of Food Chemistry, Vol. 116, No. 4, 2009, pp. 867-872. doi:10.1016/j.foodchem.2009.03.036

[29] O. A. Odukoya, S. I. Inya-Agha, F. I. Segun, M. O. Sofidiya and O. O. Ilori, "Antioxidant Activity of Selected Nigerian Green Leafy Vegetable," American Journal of Food Technology, Vol. 2, No. 3, 2007, pp. 169-175. doi:10.3923/ajft.2007.169.175

[30] A. Lipkin, A. Veronika, N. Aleksandra, B. Aleksey, K. Eberhardt, L. B. Mikhae, G. Eugene and E. Tsezi, "An Antimicrobial Peptide Ar-AMP from Amaranth (Amaranthus retroflexus L.) Seeds," Journal of Science Direct, Vol. 32, No. 1, 2004, pp. 93-95.

[31] Y. Z. Cai, M. Sun and H. Croke, "Characterization and Application of Betalian Pigment of Plant Amaranthaceae," Trend in food and Science Technology, Vol. 16, No. 9, 2005, pp. 370-376. 